\title{
THE DIPLOMATIC RELATIONS BETWEEN THE REPUBLIC OF MACEDONIA AND THE REPUBLIC OF GREECE AFTER SIGNING OF THE INTERIM AGREEMENT FROM 1995 TO 2008
}

\author{
Miroslav Adji-Andov, \\ Faculty of Law at University "Goce Delchev"-Stip, Macedonia \\ i_natalija@yahoo.com
}

Professional Paper doi:10.5937/jouproman6-18189

\begin{abstract}
Diplomacy is an art and/or practice of negotiating between certain states leaders. Namely, all international agreements are commonly negotiated between diplomats, before those same contracts are accepted by national politicians.

International diplomacy in the world system also takes place through numerous events, personal conversations between diplomats, electronic communications, etc. In fact, an important element of diplomacy is working on current problems between states through negotiating.

Most often, the leaders of certain states can not agree on some issues related to trade or foreign policy, or other issues of relevance to them, so here instead of using violence to resolve a specific dispute, diplomacy is used to find out solution. There are numerous cases of diplomacy in international relations, as well as case studies of invested diplomatic efforts between different countries. Although diplomacy has been an integral part of international relations for centuries, but still remains the most critical component in international relations.

In this paper, we focus on perceiving the overall diplomatic relations between the Republic of Macedonia and the Republic of Greece after signing of the interim agreement from 1995 to 2008 , on the other hand.
\end{abstract}

Key words: dispute; negotiations; foreign policy; compromise; solution.

\section{Introduction}

The subject of this paper is the activities, the influence and the activity of the Macedonian diplomacy in dealing with the imposed problem of the name of the state. The idea of analyzing Macedonia's diplomacy regarding the name issue with our southern neighbor comes from the long-standing inability to resolve this dispute, as well as the stagnation of the Republic of Macedonia in the European integration processes, as one of the main goals of the Macedonian foreign policy. After its independence, the Republic of Macedonia has made efforts to build a diplomatic network.

The Republic of Macedonia, immediately after the proclamation of independence on September 8, 1991, is facing trouble because of its name with its southern neighbor Greece. The attitude of Greece can hardly be broken, according to which the existence of a state called Macedonia threatens its territorial integrity. Greece several times introduced various economic blockades and used a veto for membership of the Republic of Macedonia in international organizations. The Republic of Greece is on the side of a name that contains in itself geographical terminology, which will be used in both bilateral relations and internationally. The Republic of Macedonia insists in its relations with Greece to use a name in respect of which the two countries will reach agreement, and in its international relations or relations with other countries to use its constitutional name Republic of Macedonia. 
It seems that the two countries came closest to their attitudes in 1995 with the signing of the interim agreement.

\section{The diplomatic relations between the Republic of Macedonia and the Republic of Greece after signing of the interim agreement from 1995 to 2008}

After the signing of this agreement, the second phase is taking place, where the cooperation on the economic plane is normalized and diplomatic relations between Greece and Macedonia are established (Frckoski Danailov, 2009). Bilateral relations between Macedonia and Greece were established and formally began with the signing of the 1995 Interim Accord in New York (Floudas, 2002, p.85). With the Interim Accord, the two parties undertook obligations, such as:

- Change of the flag of Macedonia and amendment of the Constitution in the preamble, where it is determined that the Republic of Macedonia has no territorial pretensions towards any of its neighbors;

- Greece assumed an obligation not to prevent Macedonia from joining international institutions (OSCE, EU, NATO, etc.), and the membership application could be submitted with the constitutional name, but Greece still retained the right to block the admission of state in such institutions if the receipt was not under the temporary reference.

In the 1995 interim agreement, the contracting parties are determined as the first and second pages or by the names of the the capital cities of both countries, Skopje and Athens.
When signing agreements on a bilateral level, the Republic of Macedonia does not use the temporary reference, and if the Greek Contracting Party insists on such a reference, then the first contracting party to the agreement shall be printed in two versions (one under the constitutional name of the Republic of Macedonia and another under the temporary reference), so each party signs only the version that is acceptable to her.

When signing agreements at the multilateral level by Macedonia not signed any deal where not specified constitutional name, and in such a case, by sending letters, the Republic of Macedonia gives a notification of the other party that is a signatory to the agreement that is agreeable to such an agreement and that that agreement will be applied in the Republic of Macedonia and it is signed by the responsible authority, but using the constitutional name of the state.

And then, in that period, as in the present, on the territory of the Republic of Greece, the "Slav Macedonians" are not recognized as a minority with a different ethnic culture.

The same day after the Interim Accord between Greece and Macedonia was signed, a letter was sent from US President Bill Clinton, which contained the information that full diplomatic relations between the United States and the Republic of Macedonia are being established. Macedonian President Gligorov sent a telegram to the President of Greece Stephanopoulos and Prime Minister Papandreou, which received a return response highlighting the improvement of relations between the two sides. 
At that time, a message was sent to the Security Council by the mediator Cyrus Vance for the signing of the Interim Accord between Greece and Macedonia (Gligorov, 2002, p.411). The Interim Accord was ratified in early October 1995 by the Assembly of the Republic of Macedonia, and also in that period by the Parliament of Macedonia, the Law on the new flag with 8 slings was also adopted. With the adoption of this law, the new flag became the necessary condition, so the new flag was raised in front of the United Nations headquarters in New York.

Then, in the middle of October 1995 between the representatives of Macedonia and Greece, a Memorandum was signed on the practical measures for applying the Interim Accord, and the Greek embargo was abolished in 1994, and the border between the two countries was open to cooperation.

In Greece, on 20 October 1995, the following contracts were signed: Memorandum for opening of liaison offices in Skopje and Athens, Protocol on mutual visa regime and fees, Protocol on transport and communication, etc. This was the end of the period of blockades and embargoes towards the Republic of Macedonia, which period was extremely difficult for Macedonia.

However, the problems of the Republic of Macedonia have not stopped with this, but she continued her struggle for recognition of the name and its international representation (Mitev, 2015, p.90-102).

At the beginning of Macedonia's independence, foreign policy was aimed at building good relations with all neighboring countries, but avoiding a privileged relationship with any neighboring country. This foreign policy was a result of the negative past experiences, and it ended in 1998 with the formation of a new Government of the Republic of Macedonia. Then, a foreign policy with positive approach and closer relations with neighbors (especially Bulgaria and Greece) began to be implemented.

Such a positive foreign policy was interrupted in 2001 with the conflict, after which a broad ruling coalition was formed in Macedonia, and the whole concentration was directed towards dealing with the crisis. After the regular parliamentary elections in 2002, a new ruling coalition was formed, which also focused primarily on tackling the aftermath of the 2001 conflict. Despite the formation of a new government after the regular elections in 2006 and the early elections in 2008, the Macedonian foreign policy consistently lacked a new, publicly promoted approach to its neighbors (Marolov, Rodriguesb, 2014, p.260-267).

Although the Republic of Macedonia named its own representative at the headquarters in Brussels in October 1992, however, the overall diplomatic relations with the European Union were realized in December 1995, when the Republic of Macedonia opened the mission to the European Union. In 1997, the Republic of Macedonia signed the Cooperation Agreement with the European Community. The same year, the Permanent Mission of the European Commission to the Republic of Macedonia was opened. In the period from April to November 2000, the Republic of Macedonia negotiated a Stabilization and Association Agreement. 
The text of the Stabilization and Association Agreement was approved at the Summit of Heads of State and Government of the member states of Hungary, held in Zagreb in 2000 (Report from the Commission on the feasibility of the Stabilization and Association Negotiations Agreement with the former Yugoslav Republic of Macedonia, 1999, p.3). The agreement was signed in Luxembourg on April 9, 2001, which ended the negotiation process. The Stabilization and Association Agreement entered into force on April 1, 2004 after the ratification of all member states in the European Union. The Republic of Macedonia was the first country in the region to sign the Stabilization and Association Agreement and clearly focused on the road to the European integration path. One of the most important chapters of the Stabilization and Association Agreement regarding EU membership for the countries of the Western Balkans is the Regulation on Regional Stability and Cooperation as an additional criterion.

The interpretation of this term "regional stability" would mean that the Republic of Greece could invoke a solution to the name dispute with the Republic of Macedonia in relation to the country's integration into the European Union. This regional stability was clearly defined by the European Union at a meeting of the European Council in Cologne in 1997 (Taskovska, 2004, p.5758).

In 2001, the International Crisis Group proposed three elements for a solution, such as:

- A bilateral agreement between the two countries where Macedonia will make concessions at the expense of Greece regarding the Greek cultural heritage in curricula in Macedonia, to allow Greece to use its name for the Republic of Macedonia and protection against possible opportunity to Macedonia's constitutional name to use at the expense of Greece;

- The member states of the European Union and NATO to support such a bilateral agreement by sending diplomatic notes to the contracting parties, where the Macedonian name will be recognized, and Greece will be promised to consult all countries with it in case of breach of contract;

- All international organizations use the constitutional name Republic of Macedonia in Macedonian language in their functioning.

For post-communist countries, NATO membership precedes membership in the EU, which guarantees the fulfillment of political criteria. Subsequently, the process of EU membership continues to meet the economic and legal criteria envisioned in Copenhagen in 1993. So, it can be expected that the Republic of Macedonia should first join NATO with fulfillment of political criteria, and then continue its path to the EU in fulfillment of legal and economic criteria prescribed in Copenhagen.

In 2007, the European Community signed a visa association agreement with Albania, Bosnia and Herzegovina, Republic of Macedonia, Montenegro and Serbia, in order to facilitate issuing visas for a short period of stay for the citizens. The Republic of Macedonia has signed the Readmission Agreement with the European Community and the Member States. The Council of Ministers of the Interior and Justice met at the meeting in Brussels to decide on the elimination of the Schengen visa barriers for the Republic of Macedonia, Montenegro and Serbia, starting from the end of December 2009 (Chavkovska, 2015, p.403-414). 


\section{Conclusion}

The Republic of Macedonia has been fighting for its independence for more than 20 years, overcoming many obstacles and challenges. The biggest temptation is the country's entry into the United Nations under the provisional name of the former Yugoslav Republic of Macedonia, in order to meet the requirements in the name dispute with its southern neighbor Greece. Fifteen years later, in 2008, in terms of NATO membership, the situation is repeated again, so that Greece confirms the influence of the superpower and its final role on the international stage.

\section{References}

> Frckoski Danailov, Lj. (2009). The character of the name dispute between Macedonia and Greece. Progress Institute for Social Democracy, Skopje.

$>$ Floudas, D.A. (2002). „Pardon? A name for a conflict? FYROM'S dispute with Greece" revisited in: kourvetaris et al(eds.), the new Balkans, East europeaean monographs: Columbija University Press.

> Gligorov, K. (2002). Macedonia is everything we have. Culture, Skopje.

$>$ Mitev, O. (2015). Creation of an independent Republic of Macedonia - Master's thesis. University "Goce Delcev", Stip.

$>$ Marolov, D.; Rodriguesb, N. J. (2014). Theoretical and Legal Framework of Foreign Policy the Example of the Republic of Macedonia - Official EU Candidate Country. International Journal of Sciences: Basic and Applied Research (IJSBAR) ISSN 2307-4531 (Print\&Online)http://gssrr.org/index.php?journ al=JournalOfBasicAndApplied, Vol. 13, num.1.

$>$ Report from the Commission on the feasibility of the Stabilization and Association Negotiations with the former Yugoslav Republic of Macedonia, COM (1999) 300 final, Brusels.

$>$ Taskovska, D. (2004). The sun remains sun. Faculty of Law "Iustinianus Primus" Skopje.

$>$ Gotton, Z. (2006). European law. Congress Service Center, LLC, Skopje.
Chavkovska, B. (2015). Is the Republic od Macedonia "good lover?" Republic od Macedonia - NATO-EU case study. Vizione. 